\title{
Screening of Botrytis Gray Mould Disease of Chickpea As Compared With Field Screening Techniques and Cut-Twig Method
}

\author{
M. H. Rashid ${ }^{1}$ and M. A. Hossain ${ }^{2}$ \\ ${ }^{I}$ Principal Scientific Officer, On-Farm Research Division, Agricultural Research Station, Bangladesh \\ Agricultural Research Institute, Daulatpur, Khulna, Bangladesh and ${ }^{2}$ Principal Scientific Officer, Pulse \\ Research Sub-Station, Bangladesh Agricultural Research Institute, Gazipur, Bangladesh
}

\begin{abstract}
A field trial was carried out on the suppression of botrytis gray mould (BGM) of chickpea using various chickpea lines at Regional Agricultural Research Station (RARS), BARI, Rahmatpur, Barisal, Bangladesh during 2012-2013. Both field screening techniques and cut-twig method were applied to control the disease. Spore suspensions of BGM were applied at flower initiation stage in the field trial. In the field screening, out of 29 chickpea lines, the entries 14, 4, 9 and 2 showed 4, 5, 6 and 7 disease scoring scale, respectively. In case of cut-twig method out of 29 chickpea lines, the entries 4, 5, 10, 6 showed 4 5, 6, and 7 scoring scales, respectively. For both field screening and cut-twig method a total of four lines viz., ICCL 87322, ICC 4971, ICC 4936 and ICC 1680 entries showed resistant reaction to BGM. The highest yield under field screening technique was obtained from the line ICC 14559 (2403 kg/ha) followed by ICCX 860029-BH-1PN$B P N-B(2161 \mathrm{~kg} / \mathrm{ha})$ and both are showed 4 grading scale. Although, field screening of chickpea genotypes is the widely practiced method, but screening in growth rooms and screen houses require temperature and humidity control facilities, that are not always available for researches in developing countries. Moreover, cut twig method is a quick and comprehensive screening technique and applicable to all areas in the world for controlling chickpea BGM.
\end{abstract}

Keyword: Screening, BGM. Chickpea

\section{Introduction}

Chickpea (Cicer arietinum L.), the world's third most important food legume, rests on a narrow genetic base because of its single domestication and self-pollinaton nature. One of the best and proven means to broaden the genetic base of the crop, and also to introduce newer sources of resistance to various biotic and abiotic constraints, is to create interspecific hybrids of the plant, and more, by utilizing the wild species of chickpea for the purpose. Globally a total of 172 pathogens which include fungi, bacteria, virus, nematodea and mycoplasma like organisms have been recorded on chickpea growing countries of the world (Nene et al., 1984). Botrytis gray mould (BGM), caused by Botrytis cinerea Pers. ex. Fr., is the second most potentially important disease of chickpea after Ascochyta blight (Ascochyta rabiei [Pass] Labour). BGM can devastate chickpea, resulting in complete yield loss in years of extensive winter rains and high humidity (Singh, 1997; Reddy et al. 1988; Pandey, 1988; Pande et al. 2002).

Chickpea was the third most important pulse crops up to mid nineties. But its area has gone down from 0.10 lac ha in 1990-1991 to 0.06 lakh ha in 2014-2015 and ranks $7^{\text {th }}$ among the pulses in Bangladesh (Krishi diary, 2016). Out of 126 diseases of pulses 17 diseases of chickpea so far recorded in Bangladesh (Bakr and Rashid 2007). Botrytis Gray Mold (BGM) caused by Botrytis cinerea Pers. ex. Fr., appeared as one of the most damaging diseases of chickpea in Bangladesh, which may cause 100\% yield loss (Bakr et al. 2002). It was first reported in 1981 in Bangladesh (Ahmed et al. 1981) but its recurrence after1985 drastically reduced the chickpea area and production in this country. Sixteen varieties have been released by Bangladesh Agricultural Research Institute and Bangladesh Institute of Nuclear Agriculture, but they could not create significant impact on chickpea production in the country because of BGM problem. The disease becomes serious following frequent winter rains that result in excessive vegetative growth and high humidity: which favour its infection, epidemic and severity. The disease is seed, soil and air borne. In the recent years, this disease has become a great threat to chickpea cultivation. Preventive measures such as low seed rate, chemical spray, wider row spacing, intercrop with linseed help to reduce disease intensity. But resistant cultivars offer the best solution to control the disease.

Botrytis gray mould (BGM), is an economically important disease of chickpea (Cicer arietinum L.), especially in cool, cloudy, and humid weather condition in the world. In Bangladesh BGM is the most important fungal chickpea disease, able to cause complete crop loss has reduced traditional cropping regions by $70 \%$ over the past decade. Several epidemics of BGM causing complete crop loss in the major chickpea-producing 
countries have been reported (Bakr, 1991). The pathogen B. cinerea mainly survives between seasons on infected crop debris and seeds. Despite extensive investigations on pathological, physiological, and molecular characteristics of $B$. cinerea causing gray mould type diseases on chickpea and several other hosts, the nature of infection processes and genetic basis of pathogen variability have not been clearly established. This lack of information coupled with the need for repeated application of chemical fungicides forced the deployment of host plant resistance (HPR) as a major option for BGM management. Effective and repeatable controlledenvironment and field-screening techniques have been developed for identification of HPR. Of the selected portion of chickpea germplasm evaluated for BGM resistance, only few accessions belonging to both cultivated and wild Cicer spp. were tolerant to BGM, and the search for higher levels of disease resistance continues.

Fungicide application based on disease predictive models is helpful in precision based fungicide application. Integrated disease management (IDM) of BGM has proved more effective than any of the individual disease management components in large-scale, on-farm studies conducted in India, Nepal, and Bangladesh. Further information on the biology of B. cinerea and epidemiology of the disease is needed to strengthen the IDM programs. In this paper the biology of B. cinerea including its variability, epidemiology of BGM, identified sources of resistance, and other management options, and available information on biochemical and genetic basis of disease resistance have been reviewed with a mention of future research priorities.

\section{Field screening techniques}

\section{Materials and Methods}

The trial was carried out at RARS, BARI, Rahmatpur, Barisal, Bangladesh from November 2012 to April, 2013. 29 chickpea entries were used in this trial. All the entries were supplied by ICRISAT, Hyderabad, India. The seeds were sown on 25.11.2012 in $2 \mathrm{~m}$ long single row plot allowing $45 \mathrm{x} 10 \mathrm{~cm}$ spacing. A BGM susceptible variety 'Nabin' was used after every test entries. The experiment was arranged in RCBD with two replications. Spore suspensions of BGM were applied at flower initiation stage. No fertilizer was applied in this experiment. Insecticide Decis 2.5 EC (Deltamethrin) was applied to control pod borer of chickpea. Optimum microclimate (humidity, temperature) inside the canopy were maintained by spraying plain water using mist irrigation. Water was sprayed for 30 minutes, 5 times a day with an interval of 2 hours starting from 10 AM to 6 PM. Other intercultural operations like mulching, weeding etc. were done as and when necessary. Data on plant stand, plant height, growth habit, disease score (1-9 scoring scale, Singh 1999). This modified 1-9 scale was also adopted in case of screening for resistance against Botrytis gray mould (Botrytis cinerea) of chickpea. The interpretation of the scales was as follows: $1=$ immune or Asymptomatic (I), 2 -3 = highly resistant $(\mathrm{HR}), 4-5=$ resistant (R), 6-7 = susceptible (S) and 8-9 = highly susceptible (HS) and finally yield data were recorded.

\section{Cut twig method techniques}

70 days tender shoots of chickpea plants 10 to $15 \mathrm{~cm}$ long were cut with a sterilised sharp edge blade in the evening. The lower portion of the twig is wrapped with a cotton plug and transferred to a test tube and placed in a plastic box in sterilised sand. Immediate after placement of twig the boxes were taken in the laboratory. After one day the boxes were opened and sprayed with BGM spore suspension. After seven days the symptom developed. Disease prevalence were recorded using 1-9 scoring scale.

\section{Results and discussion}

The performances of different chickpea entries for their relative resistance/tolerance to BGM are presented in Table 1-3. Final plant stands of all the entries were good. Disease pressure was very high due to application of mist irrigation. Mean disease scores varied from 4-7. Some of the entries having tall, erect plant type showed tolerant reaction to BGM (score 4). Out of 29 chickpea lines 14, 4, 9 and 2 entries showed 4, 5, 6 and 7 scoring scale respectively. No entries were found in 1, 2, 3, 8 and 9 scoring scale (Table 1). The lowest disease score was recorded in the entries ICC 739, ICCX850498-3PN-17H-BH-BH, ICC 13810, ICC 12952 , ICCL 87322, ICC14559, ICC 4954, ICCX 880030-BP-BP-6PN-BPN-BN, ICCV 98505, ICCV 89302, ICC 1807, ICC 4971, ICCX 860029-BH-1PN-BPN-B and ICC 12339, ICC 1680, ICC 4936, ICCX 860023-BP-BPBP-3P-BH-1H-BH and ICCX $860030-B P-B P$ belonging to 4 and 5 scoring scale. It was observed that all the lines having short and bushy canopy structure showed high susceptibility to BGM disease. This may be due to long duration of high humidity inside the canopy coverage, which favoured rapid disease development. Some entries showed high level of susceptibility and failed to produce any grain. 
Table 1. Screening of 29 chickpea lines against BGM during 2012-2013 in the field

\begin{tabular}{|l|c|c|}
\hline Name of the entries & Disease severity (1-9) & Disease reaction \\
\hline ICC 739, ICCX850498-3PN-17H-BH-BH, ICC 13810, ICC 12952, ICCL 87322, & 4 \\
ICC14559, ICC 4954, ICCX 880030-BP-BP-6PN-BPN-BN, ICCV 98505, ICCV & \\
89302, ICC 1807, ICC 4971, ICCX 860029-BH-1PN-BPN-B and ICC 12339 (14) & Resistant \\
ICC 1680, ICC 4936, ICCX 860023-BP-BP-BP-3P-BH-1H-BH and ICCX 860030- & 5 \\
BP-BP (4) & 6 \\
\hline ICCV 89303, ICC 14824, ICCL 86215, ICCV 89310, ICCX880355-BH-BP-5H-BH, & Susceptible \\
ICC 1069, ICC 4951, ICC 12512 and ICC 14822 (9) & 7 \\
CCL 86242 and ICC 8509 (2) & 7 \\
\hline
\end{tabular}

Out of 17258 chickpea germplasm accessions available at ICRISAT around 2800 have been screened. A limited screening of chickpea germplasm has found no genotypes Bortytis gray mould of chickpea with high levels of resistance (Haware and Nene 1982; Ahmed, 1989; Bakr et al. 2002; Pande et al. 2002). During 2005, 428 Australian advanced chickpea breeding lines were evaluated for BGM resistance. Out of these, 99 genotypes were moderately resistant (disease reaction 4-5 on 1-9 rating scale). These lines were also highly resistant to Ascochyta blight. In comparison with cultivated Cicer species, higher levels of resistance have been found in wild Cicer species, including $C$. judaicum, C. bijugum, C. echinospermum, and C. pinnnati.dum (Singh et al. 1991; Haware 1998; Pande et al. 2002). Several wide and intra species hybridizations have been carried out to transfer the identified disease resistance in wild types and land races to commonly adopted and widely grown chickpea cultivars. Through these breeding programs a few interspecies hybrids with moderate levels of resistance to BGM and desirable agronomic traits have been identified (Singh et al. 1998).

\section{Cut twig method}

In cut twig method, 70 days old plants were cut in a sterilised blade and placed in a plastic box in sterilised sand. Immediate after placement of twig the boxes were taken in the laboratory. After one day the boxes were opened and sprayed with BGM spore suspension. After seven days the symptom developed. Data were taken 1-9 scoring scale. Result indicated that ICCL 87322, ICC 4971, ICC 4936 and ICC 1680 entries were showed resistant reaction (Table 2).

Table 2. Screening of 29 chickpea lines (ICRISAT) against BGM in cut twig method during 2012-2013

\begin{tabular}{l|c|c}
\hline Name of the entries & $\begin{array}{c}\text { Disease severity } \\
(1-9)\end{array}$ & $\begin{array}{c}\text { Disease } \\
\text { reaction }\end{array}$ \\
\hline ICCL 87322, ICC 4971, ICC 4936, ICC 1680 (4) & 5 & Resistant \\
\hline ICC 12339, ICC 1807, ICC 739, ICCX 860029-BH-1PN-BPN-B, ICCL 86215 (5) & 6 & Susceptible \\
$\begin{array}{l}\text { ICC 13810, ICC 4954, ICCV 89302, ICCV 89303, ICC 12512, ICCX 860023-BP-BP-BP- } \\
\text { 3P-BH-1H-BH, ICCX 880030-BP-BP-6PN-BPN-BN, ICC 12952, ICCX 8600302 BP-BP } \\
\text { and ICCV 98505 (10) }\end{array}$ & 7 & \\
\hline ICCX850498-3PN-17H-BH-BH, ICC 14559, ICC 8509, ICCX880355-BH-BP-5H-BH, ICC & 8 & Highly \\
4951, ICC 1069 (6) & & Susceptible \\
CCL 86242, ICC 14822, ICC 14824 and ICCV 89310 (4) & 9 & \\
\hline
\end{tabular}

This method is easy and quick for screening BGM of chickpea and it is first time done in Bangladesh. Different screening techniques have been used for screening the germplasm for BGM resistance under in vitro, greenhouse, and field conditions (Pandey et al. 2002). The cut-twig technique developed by Singh et al. (1998) offers a non-destructive sampling of the plants and is particularly useful in wide hybridization programs.

\section{Yield performance}

Yield performance of all the entries varied among themselves. Highest plant height was observed in ICCX850498-3PN-17H-BH-BH $(49.44 \mathrm{~cm})$ and ICC $12339(48.64 \mathrm{~cm})$ and lowest in ICC $14822(36.78 \mathrm{~cm})$. The highest number of branch per plant was recorded in ICC 4954(3.66) and ICCX880355-BH-BP-5H-BH (3.56) and lowest in ICC 14822 (2.44) and ICCL 87322 (2.44). The highest number of pod/plant was found in BARI chala-5 (25.08) and lowest in ICCV 98505 (6.55). The highest yield was obtained from ICC14559 (2403 $\mathrm{kg} / \mathrm{ha})$ followed by ICCX $860029-\mathrm{BH}-1 \mathrm{PN}-\mathrm{BPN}-\mathrm{B}(2161 \mathrm{~kg} / \mathrm{ha})$ which were included in 4 grading scale. This variation may be due to i) the effect of BGM on formation of grains ii) variation of makeup of chickpea entries and iii) growing condition of plants. 
Screening Of Botrytis Gray Mould Disease of Chickpea As Compared With Field Screening ..

Table 3. Yield performance of 19 chickpea lines with check under mist condition during 2012-2013

\begin{tabular}{|c|c|c|c|c|c|}
\hline $\begin{array}{l}\text { Sl. } \\
\text { No. }\end{array}$ & Pedigree & $\begin{array}{l}\text { Plant height } \\
(\mathrm{cm})\end{array}$ & No. of branch/plant & No. of pod/ plant & Yield (kg/ha) \\
\hline 1 & ICC 4951 & 37.63 def & $3.33 \mathrm{ab}$ & $20.21 \mathrm{c}$ & $2020 \mathrm{~cd}$ \\
\hline 2 & ICC 4954 & 37.00 ef & $3.66 \mathrm{a}$ & $13.33 \mathrm{e}$ & $506 \mathrm{j}$ \\
\hline 3 & ICC 4971 & $40.25 \mathrm{~b}-\mathrm{e}$ & $2.44 \mathrm{c}$ & $8.89 \mathrm{gh}$ & $508 \mathrm{j}$ \\
\hline 4 & ICC 12339 & $48.64 \mathrm{a}$ & $3.00 \mathrm{abc}$ & $8.67 \mathrm{gh}$ & $1900 \mathrm{~d}$ \\
\hline 5 & ICC 12512 & $41.27 \mathrm{bc}$ & $3.17 \mathrm{abc}$ & $22.78 \mathrm{~b}$ & $968 \mathrm{~h}$ \\
\hline 6 & ICC14559 & $38.44 \mathrm{c}-\mathrm{f}$ & $3.38 \mathrm{ab}$ & $11.33 \mathrm{f}$ & $2403 \mathrm{a}$ \\
\hline 7 & ICC 14822 & $36.78 \mathrm{f}$ & $2.44 \mathrm{c}$ & $8.44 \mathrm{~h}$ & $377 \mathrm{jk}$ \\
\hline 8 & ICCL 87322 & $39.94 b-f$ & $2.44 \mathrm{c}$ & $15.39 \mathrm{~d}$ & $1168 \mathrm{~g}$ \\
\hline 9 & ICCV 89302 & $39.78 \mathrm{~b}-\mathrm{f}$ & $3.17 \mathrm{abc}$ & $11.33 \mathrm{f}$ & $1904 \mathrm{~d}$ \\
\hline 10 & ICCV 89310 & $41.32 \mathrm{bc}$ & $3.17 \mathrm{abc}$ & $15.56 \mathrm{~d}$ & 1441 \\
\hline 11 & ICCV 98505 & $38.56 \mathrm{c}-\mathrm{f}$ & $2.44 \mathrm{c}$ & $6.56 \mathrm{i}$ & $263 \mathrm{kl}$ \\
\hline 12 & ICCL 86242 & $40.44 \mathrm{bcd}$ & $3.00 \mathrm{abc}$ & $19.56 \mathrm{c}$ & $1020 \mathrm{~h}$ \\
\hline 13 & ICCX 860030-BP-BP & $39.89 \mathrm{~b}-\mathrm{f}$ & $2.44 \mathrm{c}$ & $8.78 \mathrm{gh}$ & $461 \mathrm{j}$ \\
\hline 14 & ICCX 880030-BP-BP-6PN-BPN-BN & $42.78 \mathrm{~b}$ & $3.03 \mathrm{abc}$ & $20.00 \mathrm{c}$ & $1251 \mathrm{~g}$ \\
\hline 15 & ICCX850498-3PN-17H-BH-BH & $49.44 \mathrm{a}$ & $3.10 \mathrm{abc}$ & $10.33 \mathrm{fg}$ & $1739 \mathrm{e}$ \\
\hline 16 & ICCX 860023-BP-BP-BP-3P-BH-1H-BH & $41.31 \mathrm{bc}$ & $3.28 \mathrm{abc}$ & $19.94 \mathrm{c}$ & $650 \mathrm{i}$ \\
\hline 17 & ICCX 860029-BH-1PN-BPN-B & $39.72 b-f$ & $2.61 \mathrm{bc}$ & $9.11 \mathrm{gh}$ & $2161 \mathrm{~b}$ \\
\hline 18 & ICCX880355-BH-BP-5H-BH & $40.28 \mathrm{~b}-\mathrm{e}$ & $3.56 \mathrm{a}$ & $23.00 \mathrm{~b}$ & 2049 bc \\
\hline 19 & BARI chala-5 (Check) & $40.95 \mathrm{bcd}$ & $3.45 \mathrm{ab}$ & $25.08 \mathrm{a}$ & $1608 \mathrm{f}$ \\
\hline \multicolumn{2}{|c|}{$\mathrm{CV}(\%)$} & 4.22 & 14.51 & 6.24 & 6.48 \\
\hline \multicolumn{2}{|c|}{$\operatorname{LSD}(0.05)$} & 2.850 & 0.72 & 1.51 & 130.4 \\
\hline
\end{tabular}

Result indicated that the entries ICCL 87322, ICC 4971, ICC 4936 and ICC 1680 showed resistant reaction (Table 3). This method is easy and quick for screening BGM of chickpea and it is first time done in Bangladesh.

\section{Reference}

[1]. Ahmed, H.U., Bakr, M.A., and Alam, K.B. 1981. Pathogen survey of major winter and summer pulses in Bangladesh. Proceeding of the National Workshop on Pulses. BARI. Joydebpur, 18- 19 August. 1981. Joydebpur, Bangladesh: Bangladesh Agricultural Research Institute.

[2]. Ahmed, Q. 1989. Field screening of chickpea varieties and cultures against gray mold (Botrytis cinerea) in Bihar, India. International Chickpea Newsletter. Vol. 21, p. 23

[3]. Bakr, M.A., S.A. Hussain, M.A. Afzal and M.A. Rahman. 2002. Chickpea status and production constraints in Bangladesh. In Integrated management of chickpea of Botrytis gray mold of chickpea in Bangladesh and Australia. Summary proceedings. Project inception workshop. BARI, Gazipur, Bangladesh. Pp. 19-32.

[4]. Bakr, M.A. 1991. Management of Important Diseases of Major Pulses. Pages 119-127 in advances of Pulses Research in Bangladesh Proc. $2^{\text {nd }}$ National Workshop on Pulses, 6-8 June 1989, Joydebpur, Bangladesh, ICRISAT, India.

[5]. Bakr, M.A. and M.H. Rashid. 2007. Strategic intervention on pulse disease research at BARI. Proceedings of Advances of Plant Pathological Research in Bangladesh (Bakr et al. eds). Gazipur, Bangladesh. February 11-12, 2007.

[6]. Haware, M.P. 1998. Diseases of chickpea, in the Pathology of Food and Pasture Legumes. D.J. Allen and J.M. Lenne, Eds., pp. 473-516, ICARDA, CAB International, Wallingford, UK,

[7]. Haware, M.P. and Y.L. Nene 1982. Screening of chickpea for resistance to botrytis gray mold. International Chickpea Newsletter. Vol. 6,pp. 17-18

[8]. Krishi diary. 2016. Agriculture Information Service. Khamarbari, Dhaka-1215.

[9]. Nene, Y.L., Sheila, V.K. and Sharma, S.B. 1984. A world list of chickpea (Cicer arietinum) and pigeonpea (Cajanus cajan (L.) Millsp.) pathogens. ICRISAT Pulse Pathology Progress Report 32, Patancheru, Andhra Pradesh, India.

[10]. Pande, S., Singh, G., Rao, J.N., Bakr, M.A., Chaurasia, P.C.P., Joshi, S., Johansen, C., Singh, S.D., Kumar, J., Rahman, M.M. and Gowda, C.L.L. 2002. Integrated management of botrytis gray mold of chickpea. Information Bulletin No. 61, ICRISAT, Andhra Pradesh, India.

[11]. Pandey, B.K. 1988. Studies on Botrytis gray mold of chickpea (Cicer arietinum L.). PhD thesis, Govind Ballabh Pant University of Agriculture and Technology, Pantnagar, Uttar Pradesh, India.

[12]. Reddy, M.V., Singh, Onkar and Bharati, M.P., Sah, R.P. and Joshi, S. 1988. Botrytis gray mold epiphytotic of chickpea in Nepal. International Chickpea Newsletter 19p. 15.

[13]. Singh, G. 1997. Epidemiology of botrytis gray mold of chickpea. Pages 47-50in: Recent advances in research on botrytis gray mold of chickpea (Haware, M.P., Lenne, J.M., and Gowda, C.L.L., eds.). Patancheru 502 324, Andhra Pradesh, India: International Crops Research Institute for the Semi-Arid Tropics.

[14]. Singh, G. 1999, Proposed rating scale for BGM of chickpea. BGM Newsletter 2(1):5-6. 